\title{
Article \\ Understanding FinTech Platform Adoption: Impacts of Perceived Value and Perceived Risk
}

\author{
Jianli Xie ${ }^{1}$, Liying Ye ${ }^{2}$, Wei Huang ${ }^{2,1}$ and Min Ye ${ }^{1, *}$ \\ 1 Department of Information Management, School of Management, Xi'an Jiaotong University, \\ No. 28 Xianning West Road, Xi'an 710049, China; xiejianli029@stu.xjtu.edu.cn \\ 2 College of Business, Southern University of Science and Technology, No. 1088 Xueyuan Avenue, \\ Nanshan District, Shenzhen 518055, China; yely@sustech.edu.cn (L.Y.); huangw7@sustech.edu.cn (W.H.) \\ * Correspondence: ymparry@stu.xjtu.edu.cn
}

Citation: Xie, J.; Ye, L.; Huang, W.; Ye, M. Understanding FinTech Platform Adoption: Impacts of Perceived Value and Perceived Risk. J Theor. Appl. Electron. Commer. Res. 2021, 16, 1893-1911. https:// doi.org/10.3390/jtaer16050106

Academic Editors: Jorge Bernardino and Eduardo Álvarez-Miranda

Received: 12 April 2021

Accepted: 2 June 2021

Published: 17 June 2021

Publisher's Note: MDPI stays neutral with regard to jurisdictional claims in published maps and institutional affiliations.

Copyright: (c) 2021 by the authors. Licensee MDPI, Basel, Switzerland. This article is an open access article distributed under the terms and conditions of the Creative Commons Attribution (CC BY) license (https:/ / creativecommons.org/licenses/by/ $4.0 /)$.

\begin{abstract}
FinTech platforms are one of the most important elements in the rapidly digitized world's economy. This study investigates the factors that affected individuals' acceptance of FinTech services, especially on internet wealth management platforms. The current research extends the unified theory of acceptance and use of technology (UTAUT) published by MIS Quarterly with integrated financial consumption attributes (i.e., perceived value and perceived risk) alongside the core construct of UTAUT. Data were collected from an established survey company. The empirical results indicate that perceived value, perceived risk, and social influence are strongly related to individuals' FinTech adoption intention, whereas performance expectancy, effort expectancy, and perceived risk affect individuals' perceived value, which in turn influences adoption intention. The proposed FinTech adoption model could contribute to information technology (IT) adoption research by extending the UTAUT in which individuals' performance expectancy and effort expectancy affect their adoption intention indirectly through perceived value. Finally, the implications of the proposed new model for future research and FinTech practice are discussed.
\end{abstract}

Keywords: FinTech platform; IT adoption; UTAUT; perceived value; perceived risk

\section{Introduction}

With the deepening integration of internet technology and the financial industry, FinTech has offered the public innovative financial services [1] such as online payment, peer-to-peer lending, budgeting and financial planning, crowdfunding, and savings and investments. The adoption rate of FinTech services has surged from 33\% in 2017 to $64 \%$ in 2019 [2]. The COVID-19 pandemic may have accelerated the adoption of FinTech platforms. The functions of savings and investment embedded in the internet wealth management platform is one of the top three FinTech services adopted by individuals [2]. According to [2], $78 \%$ of individuals are aware of the saving and investment service offered by FinTech platforms. By the end of 2019, 34\% of individuals globally accessed savings and investment services from internet wealth management platforms.

A wealth management platform refers to an online platform offering internet financial products and/or services, including savings and investments. For example, in China, the most widely used internet wealth management platform is Yu'E Bao. Unlike traditional wealth management services, it provides both saving and investment functions. People put their money in Yu'E Bao, which allows them to buy internet fund products and the money to be used in shopping and payments directly. Internet wealth management platforms offered by FinTech companies have already spurred change across the wealth management services industry. Some internet financial companies are stepping into the FinTech market, and incumbents, such as banks, accelerate their transformation. With the enthusiastic use of internet wealth management platforms offered by FinTech companies, further research 
needs to explore the factors that influence individuals' FinTech adoption focus in such a specific context.

FinTech related research can be classified into two categories. One stream of the research on FinTech mainly focuses on its revolution and effects on the incumbent financial industry [3-6]. This stream of work contributes to the expansion of understanding of the mechanisms of FinTech platforms. The other stream of work focuses on investigating the factors that affect Fintech platforms' adoption. The wider adoption of FinTech platforms depends on individuals' access to new technologies. Therefore, FinTech adoption behavior could be regarded as financial technology adoption behavior to some extent. The unified theory of acceptance and use of technology (UTAUT) [7] is widely used as the baseline model for understanding FinTech adoption intention or behavior [8-10]. Previous research focuses on exploring the financial-related adoption behavior from the perspective of technology adoption and contributes to our understanding of FinTech platforms $[1,8,9,11-14]$. However, most studies focus on specific FinTech services such as online banking, and online payments, as well as peer-to-peer lending [9,15-27]. Few of them explore factors that affect individuals' online wealth management platforms.

Logically, individuals' FinTech adoption behavior manifests in both technology adoption behavior and financial services consumption behavior. Financial services consumption refers to the processes where consumers access and use financial products such as internet fund products and/or services. In this paper, we focus on the internet wealth management platforms of FinTech services. Several studies on consumer behavior indicate that consumers' decision-making behavior largely depends on utility maximization [28-31]. Perceived value is related to consumer behavior [28,32]. Moreover, the risk nature of financial products and the uncertainty of e-commerce are the main obstacles that affect individuals' use of FinTech platforms, especially for internet wealth management platforms [33-38]. As the main attributes of financial services consumption, the two constructs, the perceived risk and perceived value, have been studied separately in prior research. There are mixed findings on the impact of perceived risk on individuals' FinTech adoption-related behavior $[23,39,40]$. Especially for internet wealth management platforms, few studies integrated the two constructs into UTAUT in the FinTech adoption context. Although previous research is valuable in extending FinTech platform adoption from different perspectives, there is still a need for a comprehensive understanding of individuals' FinTech adoption from a perspective that integrates technology adoption and financial services consumption attributes.

Based on the widely used technology adoption model, this study proposes a powerful FinTech adoption model by integrating financial services consumption attributes (i.e., perceived value and perceived risk) with the UTAUT. Furthermore, the definition of perceived value has two components, "received" and "given", related to performance expectancy, effort expectancy, and perceived risk. There is a need to clarify the relationships among these constructs when integrating new constructs into the UTAUT.

This study has revealed several theoretical and practical implications. First, the current study fills the gaps mentioned earlier by exploring the factors that affect individuals' FinTech adoption of internet wealth management platforms from the financial consumption perspective. Second, this study confirms the impacts of perceived value and perceived risk on individuals' FinTech adoption in internet wealth management platforms. By adding the perceived risk and perceived value, this study extends the generalizability of the UTAUT in the FinTech adoption context. Moreover, the interactions between the UTAUT constructs and the added constructs are verified in the internet wealth management context. Clarifying the relationships among perceived value, perceived risk, performance expectancy, and effort expectancy can improve the understanding of the mechanisms of FinTech adoption-related behavior. The current study can provide practical implications for FinTech companies to design their related policies and maintain their competitiveness.

This study is organized as follows. Section 2 describes the theoretical foundation and hypotheses development. Section 3 outlines the research method, and the results are shown 
in Section 4. Finally, Section 5 discusses the main findings, followed by the theoretical and practical implications, and the limitations in Section 6.

\section{Theoretical Foundation and Hypotheses Development}

This section reviews the related theories and identifies the theory, i.e., UTAUT, explaining individuals' adoption intention in the FinTech context. We then augment FinTech related research with this theory to put forward our hypotheses.

\subsection{Theoretical Foundation}

The factors that affect individuals' information technology (IT) adoption behavior have been widely studied in sociology, psychology, and information system (IS) research. Several theoretical models were put forward during the past three decades. For example, the theory of reasoned action (TRA) [41] is one of the earliest theories used to predict the adoption behavior. Attitude toward behavior and subjective norm are the core constructs that affect individuals' adoption behavior in TRA. Davis [42] contextualized TRA to the area of IT adoption and proposed the technology acceptance model (TAM). TAM predicts that individuals' perceived usefulness and ease of use of technology, and subjective norm positively affect their adoption intention. Unlike TAM, Rogers [43] focused on innovation diffusion and put forward the innovation diffusion theory (IDT). All of these theoretical models make contributions to the IT adoption research; however, each model ignores the contributions of the others.

By synthesizing eight IT adoption-related theoretical models and their extensions (TRA [41], TAM/TAM2 [43,44], motivational model-MM [45], theory of planned behaviorTPB [46], combined TAM and TPB [47], model of PC utilization-MPCU [48], IDT [42], social cognitive theory-SCT [49]), Venkatesh et al. [50] put forward the unified theory of acceptance and use of technology model, i.e., UTAUT, in organizational contexts. The four core theoretical constructs presented in the UTAUT that influence individuals' technology adoption intention and behavior are performance expectancy, effort expectancy, social influence, and facilitating conditions [7,50]. There are four moderators: age, gender, experience, and voluntariness of use, affecting the relationship between the four constructs and adoption intention and behavior. As it gives a high explanation (as much as 70\%) for individuals' adoption intention, UTAUT has been widely applied in various fields as the fundamental model for technology adoption for individual and organizational settings in many areas [7,9,10,13,25,51-53]. Venkatesh, et al. [54] reviewed the UTAUT-related research and highlighted the direction for future UTAUT-related research. They recommended that future research should conceptualize individual-level factors (such as, technology attributes, individual attributes, task attributes) when using the UTAUT as the baseline model.

Individuals' internet wealth management platform adoption can be regarded as technology adoption, to some extent. Drawing on the four core constructs of UTAUT, this study attempts to put forward a FinTech adoption model by integrating financial services consumption attributes (perceived value and perceived risk). This study focuses on the antecedent of individuals' FinTech adoption, not the moderator. Therefore, the verification of four well-established moderators, i.e., age, gender, experience, and voluntariness of use, is not involved in this paper. The following sections show the relationships in our research model.

\subsection{Social Influence}

Social influence describes individuals' perception that essential others think he/she should adopt a technology during the technology acceptance process [7,50]. In this research, social influence is regarded as the individuals' perception of essential others (e.g., friends, family, and coworkers) who think he/she should use the internet wealth management platform. 
Venkatesh, Morris, Davis and Davis [50] pointed out that social influence positively affects individuals' adoption intention in the UTAUT. Also, numerous studies demonstrate that social impact positively affects individuals' behavioral outcomes. Yang et al. [55] reported that social influence affects individuals' M-payment adoption intention positively. Chiu et al. [56] explored the antecedents that influence people's consumption of internet sports gambling. Their conclusion implied that social influence determines an individuals' adoption attitude. Hamari and Koivisto [57] suggested that people's willingness to keep difficult habits was positively influenced by society. De Luna, Liébana-Cabanillas, SánchezFernández and Muñoz-Leiva [18] demonstrated that social influence significantly affects mobile payment systems' adoption intention. Wei, Luh, Huang and Chang [25] empirically verified that social influence affects young generations' online payment adoption. All these studies indicated that social influence positively affects individuals' intention to consume goods/services. Based on the above studies, it can be believed that individuals' adoption intention of internet wealth management platforms will be affected by essential others.

H1: Social influence is positively related to individuals' adoption intention in internet wealth management platforms.

\subsection{Facilitating Conditions}

Facilitating conditions describe the degree to which people cognize the organizational and information-technology infrastructure that would support them to adopt new technology $[7,50]$. Thus, in this study, facilitating conditions are described as individuals' perceptions of the related resources (e.g., smartphone, FinTech related applications) and supports (e.g., technical support from application vendors, technology generation) when using the internet wealth management platform. Using an internet wealth management platform needs some resources and fundamental knowledge such as the necessary financial knowledge. It is only with these facilitating conditions that individuals are likely to use a platform.

Facilitating conditions show a strong positive correlation with individuals' adoption intention. Venkatesh, Thong and $\mathrm{Xu}$ [7] confirmed that individuals' adoption intention is influenced by facilitating conditions. Subsequent studies confirmed the causal relationship between the individuals' adoption-related behavior and facilitating conditions. Some studies demonstrated that facilitating conditions are positively correlated with individuals' adoption intentions $[13,56,58]$. Oliveira et al. [59] showed that facilitating conditions affect the consumer's adoption behavior in the M-banking context. When exploring the adoption behavior of the online public grievance redressal system, Rana et al. (2016) [58] demonstrated that facilitating conditions positively and significantly affect individuals' adoption behavior. Therefore, it is expected that facilitating conditions affect individuals' adoption intention.

H2: Facilitating conditions are positively related to individuals' adoption intention in internet wealth management platforms.

\subsection{Perceived Value}

Behavioral decision theories explain that consumers' decision behavior depends on them recognizing the trade-off between the utility of decision outcomes and the effort to decide $[60,61]$. The widely used definition of perceived value is described as individuals general evaluation of the utility of goods/services, which depends on their perceptions of the "given" component and the "received" component [31]. This definition proposes that even for the same goods/services, different people have different perceived values. Similarly, the perceived value of the FinTech platform would be different among different consumers. Venkatesh, Thong and Xu [7] extended the UTAUT by adding "price value" in the consumer context. The price value is related to individuals' cognition of the trade-off between perceived benefits and the monetary cost when adopting new technology [7]. 
Viewing the perceived value from a price cost and benefit perspective would ignore the multi-dimensionality of perceived value. Besides, Jünger and Mietzner [20] empirically demonstrated that price perception does not affect individuals' FinTech adoption. Therefore, it is necessary from a more comprehensive perspective to understand the value effect on individuals' adoption behavior over various contexts [62]. Perceived value is not only monetary but also non-monetary [31]. The monetary dimension refers to financial cost. The non-monetary dimension is mainly explained as the time, effort, and other non-monetary aspects spent on the products during the consumption process [31]. Therefore, following the definition proposed by Zeithaml [31], this study defines perceived value as individuals' general evaluation of the utility of FinTech platforms, depending on their perceptions of what is "given" and "received."

Behavioral decision theory [63] justifies that individuals' decision behavior is mainly dependent on the trade-off between the utility of the decision (i.e., performance expectancy) and the effort to choose the decision (i.e., effort expectancy), which is analogous to perceived value. The definition of perceived value describes individuals' global evaluation of the FinTech platform's utility based on the two components (i.e., "received" and "given"). The perceived value represents the selection strategy's judgment, which affects the individuals' decision-making behavior [28].

Perceived value and its impacts on consumer behavior drew the attention of scholars decades ago. A mass of research showed that perceived value positively affects consumers' attitudes and behaviors $[13,28,32,62,64-66]$. A study conducted by Sweeney and Soutar [62] showed that consumers' perceived value affected their purchase intention and behavior by evaluating products' value. Kim, Chan and Gupta [28] concluded that perceived value influenced consumers' acceptance of M-internet and developed the value-based adoption of mobile internet model (VAM) through integrating the consumer choice theory with the decision-making theory. In the VAM, consumers' adoption intention of the Minternet can be explained by the perceived value. Roy [66] proposed that value could be perceived during the exchanging, using, or experiencing progress and affected consumers' behavior. Gordon, Dibb, Magee, Cooper and Waitt [32] verified that perceived value helps predict individuals' behavioral outcomes in the social marketing area. Chiu, Wang, Fang and Huang [65] proposed that utilitarian value and hedonic value affect individuals' repeat purchase intention in the online context. Shaw and Sergueeva [13] identified that perceived value positively affects consumers' intention in the mobile commerce context. Individuals' acceptance of the internet wealth management platform is financial service consumption behavior. Since the prior studies showed that individuals' perceived value affects consuming intention, the individuals' adoption intention would be influenced by the perceived value of the FinTech platform.

H3: Perceived value is positively related to individuals' adoption intention in internet wealth management platforms.

\subsection{Performance Expectancy}

Performance expectancy describes the degree that individuals believe that they would get benefits when using new technology $[7,50]$. In this study, performance expectancy refers to the degree that individuals believe that they would get benefits when using internet wealth management platforms. As mentioned before, the "received" component of perceived value refers to the benefits individuals can obtain from the FinTech platform. Performance expectancy reflects individuals' adoption action based on the desire for external rewards [50], related to the "received" component of perceived value. Prior studies have shown evidence to support that the construct of performance expectancy, such as usefulness, positively affects perceived value [28]. Therefore, it can be considered that performance expectancy affects perceived value in the same manner.

H3a: Performance expectancy is positively related to individuals' perceived value of internet wealth management platforms. 


\subsection{Effort Expectancy}

Effort expectancy describes the ease of use of new technology [7,50]. Therefore, effort expectancy in this study describes individuals' perceived ease of use of internet wealth management platforms. Effort expectancy focuses on individuals' effort when using a specific technology related to the "given" component of perceived value. The "given" component refers to the cost that individuals put into using a FinTech platform. Since most individuals adopt the FinTech platform through the mobile phone, the sizes of mobile screens, the limitations of operation, and the friendliness of the user's interface limit the effort expectancy. The effort expectancy of the FinTech platform is particularly important in this context. The construct of effort expectancy in this context is analogous to the nonmonetary cost, divided into time, search cost, etc. [31]. Effort expectancy incorporates all kinds of non-monetary costs. Therefore, the hypothesis is proposed as follows.

H3b: Effort expectancy is negatively related to individuals' perceived value of internet wealth management platforms.

\subsection{Perceived Risk}

Perceived risk is a significant impediment during the financial consuming process [67]. Regarding the definition of perceived risk, scholars have different opinions. Peter and Ryan [68] described perceived risk as to perception of loss related to purchasing, which also inhibits purchase behavior. Featherman and Pavlou [34] illustrated that perceived risk is a potential loss when an individual is using an e-service to obtain desired outcomes. Kim, Ferrin and Rao [67] combined uncertainty with potential loss and described the perceived risk as people's belief of possible negative consequences when trading online. Based on these definitions, this study defines perceived risk as individuals' perceived potential, uncertain, adverse outcomes when adopting an internet wealth management platform.

Financial transactions through the internet wealth management platforms may lead to greater concern about individuals' financial information. For example, a financial transaction could be compromised due to a technological error or accidental click error. The uncertainty should be considered as the cost of FinTech adoption, which is aligned with the "given" part of perceived value. Therefore, individuals' perceived risk could inhibit their perceived value of the FinTech platform. Thus, it is proposed that:

H3c: Perceived risk is negatively related to individuals' perceived value of internet wealth management platforms.

Risk perception is the primary inhibitor during users' adoption of new technology, especially in the e-commerce setting $[37,67,69]$. Individuals would be hesitant if they perceived risk during the online purchase process. In the proposed decision-making model, Kim, Ferrin and Rao [67] argued that the consumers' perceived risk negatively influences their intention of making transactions on the internet. Chong [69] argued that the securityand privacy-related risks associated with currency transactions through mobile devices tend to be higher since consumers' mobile devices always store their personal information.

Due to the risk features of financial products, perceived risk is considered significant when exploring FinTech adoption factors. Thakur and Srivastava [36] revealed that individuals' perceived risk negatively influences mobile payment acceptance. The result proposed by Slade et al. [70] supports this conclusion as well. De Luna, Liébana-Cabanillas, Sánchez-Fernández and Muñoz-Leiva [18] explored the factors related to accessing different M-payment platforms and demonstrated that perceived security affects consumers usage intentions on M-payment platforms. The uncertainty of e-commerce and finance risk would become the main factors hindering individuals' intention to adopt a FinTech platform. Thus, perceived risk is considered an antecedent variable that negatively affects individuals' adoption intention in internet wealth management platforms.

H4: Perceived risk is negatively related to individuals' adoption intention in internet wealth management platforms. 
Figure 1 shows the hypotheses and proposed FinTech adoption model.

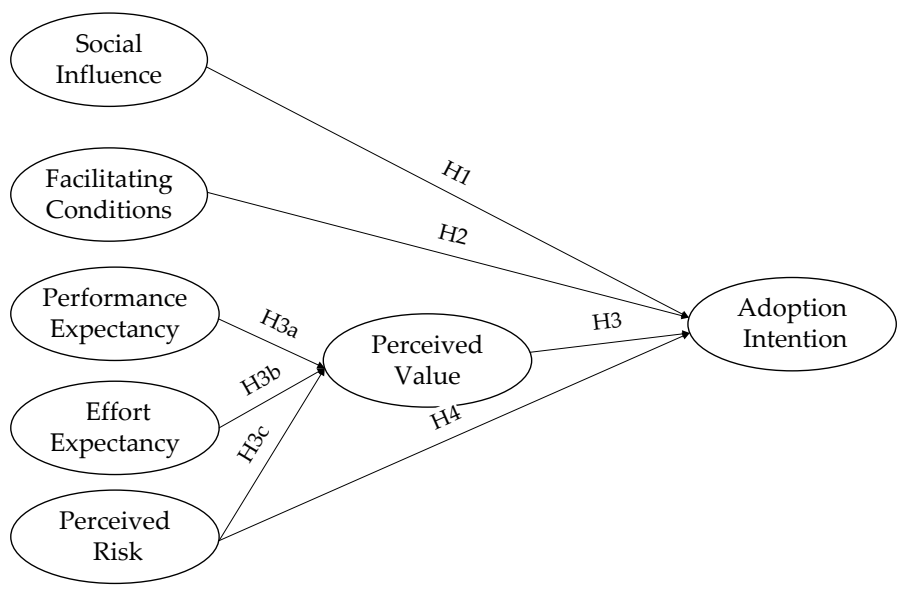

Figure 1. FinTech adoption model.

\section{Methodology}

This study explores the factors influencing individuals' FinTech adoption intention, especially focusing on internet wealth management platforms. In China, a rising number of people have accessed the internet wealth management services of FinTech platforms in recent years. Up to June 2019, more than 169 million netizens in China use internet wealth management platforms, an increase of $12.1 \%$ since the end of 2018 [71]. The high adoption rate in China is helpful for this study. Therefore, the data were collected from China in the context of internet wealth management platforms.

\subsection{Measurement}

The constructs are adapted from previous research. The scales for performance expectancy, effort expectancy, social influence, facilitating conditions, and adoption intention are adapted from the UTAUT [7,50]. The scale of perceived risk is adapted from Pavlou [72] and Kim, Ferrin and Rao [67]. The measurement for perceived value is adopted from Sirdeshmukh, Singh and Sabol [29] and Kim, Chan and Gupta [28]. Besides this, we also collected self-report adoption behavior as a robustness test. The adoption behavior was measured as a formative indicator of the frequency of FinTech wealth management platforms (ranged from "never" to "many times per day"). All items were measured on a five-point Likert scale. See Table A1 in Appendix A for details.

The questionnaire was written in English, translated into Chinese, and then translated back into English to ensure content validity [73]. Two information systems scholars and two consumer behavior researchers reviewed the questionnaire to ensure content validity further. Thirty-five people took part in preliminary surveys and interviews were conducted for the pre-test. We adjusted the language to make the whole questionnaire more concise and easier to understand based on the pre-test feedback. The pre-test data were excluded from the total dataset.

\subsection{Data Collection}

Data were collected from an online survey company in China. We received 314 responses in total. After excluding invalid questionnaires, such as missing answers and obvious irrationality, 201 responses were obtained. The total effective sample size meets the minimum sample size suggested by Hair, Black, Babin and Anderson [74], who indicates at least 150 samples for a model with seven or fewer constructs when commonalities are modest (i.e., standardized loading estimates were over 0.7 ). The 201 responses were split to $54.7 \%$ female and $45.3 \%$ male and most of them were aged from 21 to $40(75.6 \%)$. Table 1 is the descriptive demographic distribution of the subjects. 
Table 1. Demographic distribution of the subjects.

\begin{tabular}{cccc}
\hline Measure & Items & Frequency & Percentage (\%) \\
\hline \multirow{2}{*}{ Gender } & Female & 110 & 54.7 \\
& Male & 91 & 45.3 \\
& $\leq 20$ & 15 & 7.5 \\
Age & $21-30$ & 87 & 43.3 \\
& $31-40$ & 65 & 32.3 \\
& $41-50$ & 25 & 12.4 \\
& $>50$ & 9 & 4.5 \\
Educational & High school and & 27 & 13.4 \\
background & below & 73 & 36.3 \\
& Some college & 64 & 31.8 \\
& Bachelor & 21 & 10.4 \\
& Master & 16 & 8.0 \\
\hline
\end{tabular}

\section{Data Analysis and Results}

The structural equation model (SEM) was used in this study because it can model multiple dependent variables and take measurement errors into account concurrently. Two SEM techniques, namely partial least squares (PLS) and covariance-based (CBSEM), are commonly used in social science research [75]. The proposed model and measurement development were based on well-established theory. Therefore, it was more suitable to use CBSEM in the current study. Using the SPSS 26.0 and Mplus 7.0 software, the proposed model was examined.

\subsection{Measurement Model}

Table 2 shows the fit indices of the measurement model. All statistics meet the suggested value, which means that the proposed model fits the data well. Tables 3 and 4 show the reliability and validity, including the information about Cronbach's alphas, factor loadings, correlations, composite reliability (CR), and average variance extracted (AVE). Cronbach's alpha values over 0.7 and standardized item loadings (i.e., estimate) over 0.6 confirm the internal consistency reliability [76]. The value of AVE and CR show evidence of convergent and discriminant validities. The AVEs of all constructs are above 0.5 , and CR exceeds 0.6 demonstrating convergent validity [74]. The AVEs of constructs are higher than the correlations suggesting discriminant validity [74].

Table 2. Model fit for CFA.

\begin{tabular}{lcccccccc}
\hline Statistic & $\chi^{2}$ & d.f. & $\chi^{2} /$ d.f. & $\begin{array}{c}\chi^{2} \\
(p \text {-Value })\end{array}$ & CFI & TLI & RMSEA & SRMR \\
\hline $\begin{array}{l}\text { Results } \\
\text { Suggested }\end{array}$ & - & 189.286 & 1.113 & 0.137 & 0.991 & 0.988 & 0.024 & 0.041 \\
$\begin{array}{l}\text { Value } \\
\text { Reference }\end{array}$ & - & $<5$ & $p>0.05$ & $>0.9$ & $>0.9$ & $<0.08$ & $<0.1$ \\
\hline
\end{tabular}


Table 3. Standardized item loading and reliability.

\begin{tabular}{|c|c|c|c|c|c|c|c|}
\hline \multirow{2}{*}{ Construct } & \multirow{2}{*}{ Cronbach's $\alpha$} & \multirow{2}{*}{ Items } & \multicolumn{4}{|c|}{ Parameters of Significant Test } & \multirow{2}{*}{$\frac{\text { Item Reliability }}{\text { R-Square }}$} \\
\hline & & & Estimate & S.E. & Est./S.E. & $p$ & \\
\hline Performance & \multirow{3}{*}{0.794} & PE1 & 0.783 & 0.039 & 20.052 & $* * *$ & 0.613 \\
\hline Expectancy & & PE3 & 0.767 & 0.040 & 19.166 & $* * *$ & 0.588 \\
\hline$(\mathrm{PE})$ & & PE4 & 0.699 & 0.045 & 15.489 & $* * *$ & 0.488 \\
\hline Effort & \multirow{3}{*}{0.788} & EE1 & 0.751 & 0.042 & 18.082 & $* * *$ & 0.565 \\
\hline Expectancy & & EE2 & 0.711 & 0.044 & 16.040 & $* * *$ & 0.505 \\
\hline$(\mathrm{EE})$ & & EE3 & 0.771 & 0.040 & 19.210 & $* * *$ & 0.594 \\
\hline Social & \multirow{2}{*}{0.850} & SI1 & 0.834 & 0.036 & 23.064 & $* * *$ & 0.696 \\
\hline Influence (SI) & & $\mathrm{SI} 2$ & 0.886 & 0.034 & 25.725 & $* * *$ & 0.785 \\
\hline Facilitating & \multirow{3}{*}{0.787} & FC1 & 0.722 & 0.049 & 14.798 & $* * *$ & 0.521 \\
\hline \multirow{3}{*}{$\begin{array}{l}\text { Condition } \\
\text { (FC) }\end{array}$} & & FC2 & 0.808 & 0.045 & 17.943 & $* * *$ & 0.653 \\
\hline & & FC3 & 0.703 & 0.049 & 14.392 & $* * *$ & 0.494 \\
\hline & \multirow{5}{*}{0.887} & PR1 & 0.809 & 0.030 & 26.905 & $* * *$ & 0.654 \\
\hline \multirow{4}{*}{$\begin{array}{l}\text { Perceived } \\
\text { Risk (PR) }\end{array}$} & & PR2 & 0.807 & 0.030 & 26.725 & $* * *$ & 0.651 \\
\hline & & PR3 & 0.847 & 0.026 & 32.216 & $* * *$ & 0.718 \\
\hline & & PR4 & 0.796 & 0.031 & 25.484 & $* * *$ & 0.634 \\
\hline & & PV1 & 0.839 & 0.026 & 31.744 & $* * *$ & 0.704 \\
\hline Perceived & \multirow{3}{*}{0.882} & PV2 & 0.771 & 0.033 & 23.092 & $* * *$ & 0.595 \\
\hline \multirow[t]{2}{*}{ Value (PV) } & & PV3 & 0.840 & 0.026 & 31.876 & $* * *$ & 0.706 \\
\hline & & PV4 & 0.779 & 0.033 & 23.647 & $* * *$ & 0.606 \\
\hline Adoption & \multirow{3}{*}{0.857} & AIN1 & 0.832 & 0.030 & 28.204 & $* * *$ & 0.692 \\
\hline \multirow{2}{*}{$\begin{array}{l}\text { Intention } \\
\text { (AIN) }\end{array}$} & & AIN2 & 0.817 & 0.031 & 26.556 & $* * *$ & 0.668 \\
\hline & & AIN3 & 0.800 & 0.032 & 24.699 & $* * *$ & 0.640 \\
\hline
\end{tabular}

Note: ${ }^{* * *} p<0.001$.

Table 4. CR, AVE, and correlations.

\begin{tabular}{cccccccccc}
\hline Construct & CR & AVE & PE & EE & SI & FC & PR & PV & AIN \\
\hline PE & 0.794 & 0.563 & $\mathbf{0 . 7 5 0}$ & & & & & & \\
EE & 0.789 & 0.555 & 0.666 & $\mathbf{0 . 7 4 5}$ & & & & & \\
SI & 0.851 & 0.740 & 0.633 & 0.471 & $\mathbf{0 . 8 6 0}$ & & & & \\
PR & 0.888 & 0.664 & -0.265 & -0.198 & -0.183 & $\mathbf{0 . 8 1 5}$ & & & \\
PV & 0.882 & 0.653 & 0.661 & 0.734 & 0.600 & -0.332 & $\mathbf{0 . 8 0 8}$ & & \\
FC & 0.789 & 0.556 & 0.274 & 0.249 & 0.317 & -0.083 & 0.149 & $\mathbf{0 . 7 4 6}$ & \\
BI & 0.857 & 0.667 & 0.456 & 0.390 & 0.484 & -0.689 & 0.597 & 0.181 & $\mathbf{0 . 8 1 7}$ \\
\hline
\end{tabular}

Notes: The square root of the AVE value is shown in bold, and off-diagonal elements are correlations.

This study used variance inflation factors (VIF) to examine whether the proposed FinTech adoption model suffers from multicollinearity. The VIF values ranged from 1.777 to 2.100, below the threshold recommended [74]. Therefore, multicollinearity was not a significant threat to the regression analysis. In addition, this study adopted procedural techniques to control common method biases [79]. Three procedural techniques were used to control method biases: (1) the first part of the questionnaire contained a participants' privacy protection commitment to protect their anonymity and reduce apprehension about the evaluation; (2) randomizing the scale order of each item; (3) inviting experts to review the questionnaire to ensure it was concise and simple. Harman's single-factor test was conducted to examine any method biases. Seven factors accounted for $75.435 \%$ of the variance, and the first factor accounted for $34.411 \%$ of the data variance (see Table A3 in Appendix B). The results showed that no factor could explain the major part of the data [79-81]. Therefore, the common method biases were not a major problem for the results.

\subsection{Structural Model}

The results from Mplus 7.0 showed that the structural model fitted well: $\chi^{2} / d f=1.153$, $p=0.071, \mathrm{CFI}=0.987, \mathrm{TLI}=0.984$ and SRME $=0.044, \mathrm{RMSEA}=0.028$ (90\% CI: 0.000, 0.043). 
Figure 2 shows us that social influence positively affected $(0.210, p<0.01)$ adoption intention, validating $\mathrm{H} 1$. The path coefficient between facilitating condition and adoption intention was not significant $(0.022, p=0.733)$. Therefore, $\mathrm{H} 2$ was not supported. Perceived value was positively related to adoption intention $(0.286, p<0.001)$, thus H3 was supported. Next, performance expectancy $(0.317, p<0.001)$, effort expectancy $(0.496, p<0.001)$, and perceived risk $(0.154, p<0.05)$ were significantly correlated with perceived value $\left(\mathrm{R}^{2}=0.634\right)$, which supported $\mathrm{H} 3 \mathrm{a}, \mathrm{H} 3 \mathrm{~b}$, and H3c. Perceived risk showed a strongly negative effect $(-0.556, p<0.001)$ on adoption intention, indicating that H4 was supported.

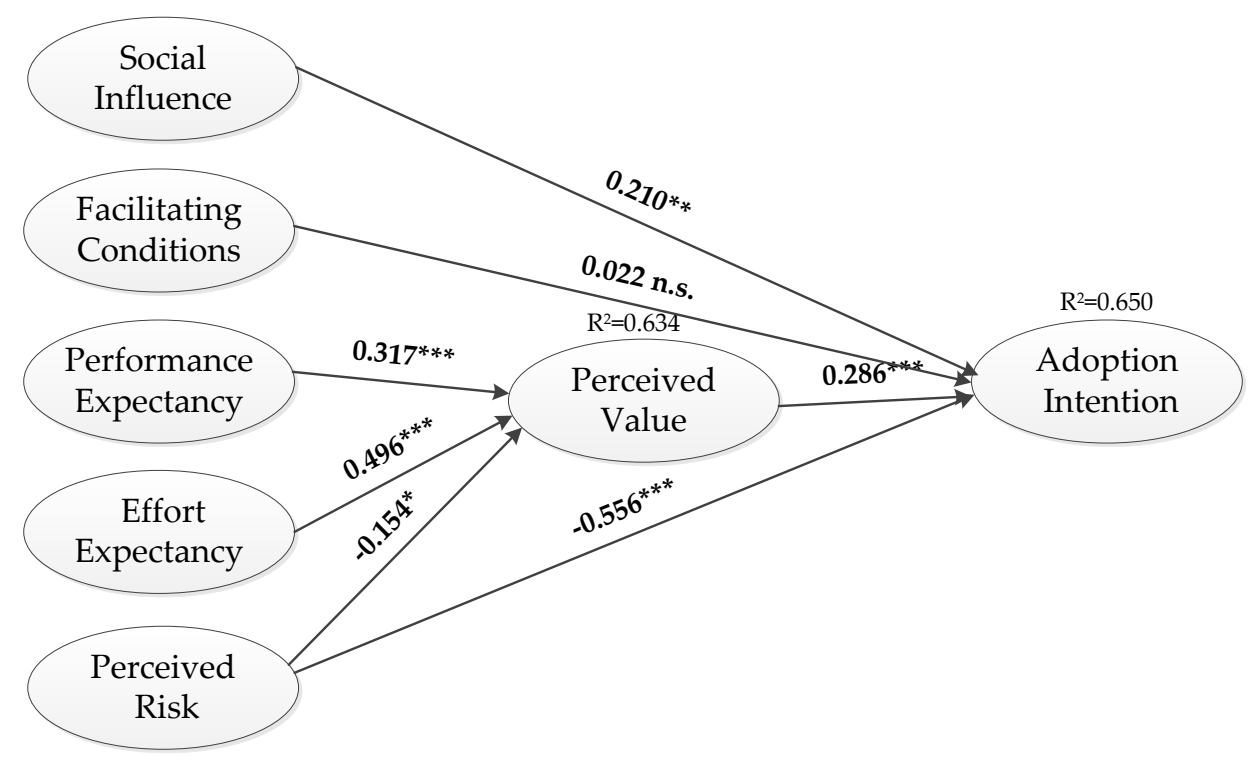

Figure 2. The results of the FinTech adoption model. Note: ${ }^{* *} p<0.001$; ${ }^{* *} p<0.01 ;{ }^{*} p<0.05$; n.s.: no significance.

Lastly, we conducted a robustness test to verify that the proposed FinTech adoption model was also able to explicate FinTech adoption behavior. Similar to the relationship with FinTech adoption intention, the results of the alternative model showed evidence of the robustness of the proposed FinTech adoption model (see Appendix C).

\section{Conclusions and Discussion}

This study investigated the factors that influence individuals' FinTech adoption behavior focus, especially on internet wealth management platforms, by combining perceived value and perceived risk with the core constructs of UTAUT. The proposed FinTech adoption model explained individuals' adoption intention with 65\% variance. The results show that social influence $(\mathrm{H} 1)$ and perceived value $(\mathrm{H} 3)$ positively affect adoption intention, while perceived risk (H4) negatively affects adoption intention. Performance expectancy (H3a), effort expectancy (H3b), and perceived risk (H3c) affect individuals' perceived value of the FinTech platform. Facilitating conditions (H2) do not affect individuals' adoption intention.

Perceived value, which is affected by performance expectancy, effort expectancy, and perceived risk, is a notable driver of FinTech adoption intention in internet wealth management platforms. This conclusion is consistent with the behavioral decision theory, which explains consumers' decision behavior depends on recognizing the trade-off between the effort to make a decision and the quality of the decision $[60,61]$. Perceived value was suggested to predict a person's using intention in many kinds of research [13,28,32,62]. Shaw and Sergueeva [13] confirmed the correlation between perceived value and adoption intention in a mobile consumption context. Individuals are more likely to use internet wealth management platforms if their perceived value is high. Our conclusion supports this 
argument, i.e., perceived value directly affects individuals' adoption intention of internet wealth management platforms.

Moreover, the empirical result shows that performance expectancy, effort expectancy, and perceived risk directly affect perceived value. Individuals' performance expectancy positively affects perceived value, which means the utilities of adopting FinTech platforms could influence individuals' assessment of the platform's value. The more usefulness and efficiency the internet wealth management platform provides, the higher the perceived value. At the same time, effort expectancy showed a positive effect on perceived value in this research. Thus, individuals' perceived value of the FinTech platform is influence by the extent of ease of use.

Perceived risk reflects the uncertainty of financial services consumption on internet wealth management platforms and individuals' perceived risk is negatively related to perceived value. The result also proved that the partitioning of perceived value's antecedent as "received" and "given" components related to the performance expectancy, effort expectancy, and perceived risk is reasonable.

More importantly, perceived risk affects individuals' perceived value and is the most significant inhibitor of individuals' adoption intention in the FinTech setting. Previous research has also confirmed the correlation between perceived risk and adoption intention in e-commerce and online banking areas $[9,33,39,65]$. However, mixed findings exist about the impact of perceived risk on individuals' adoption in mobile payment areas $[23,40]$. The current study shows that the perceived risk is the core inhibitor for individuals' internet wealth management platforms adoption. The FinTech consumption complexity and the separation of time and space increase individuals' perception of risk, thereby decreasing adoption intention.

In line with the UTAUT, social influence positively influences adoption intention in the internet wealth management context $[7,50]$. Although there is evidence from previous research that supports these results for some specific FinTech services $[10,17,25]$, some studies did not show similar results $[8,13]$. Besides this, facilitating conditions are insignificant factors for adoption intention in the FinTech context. Venkatesh, Morris, Davis and Davis [50] argued that the correlation relationship between facilitating condition and adoption intention would disappear when including the effort expectancy in the whole model. The insignificant correlation between facilitating condition and adoption intention has also been found in mobile consumption and internet banking contexts [13,25,39].

\section{Contributions and Limitations}

\subsection{Theoretical Contributions}

Based on the UTAUT, this study proposes a comprehensive model that predicts individuals' FinTech adoption intention focus, especially on internet wealth management platforms, by integrating financial services consumption attributes (perceived value and perceived risk). It is worth noting that the added constructs, namely perceived value and perceived risk, are compatible with the UTAUT. Although these two factors have been studied separately in previous research, they were simultaneously verified in the FinTech context, especially on internet wealth management platforms. The proposed model provides a comprehensive perspective to understand FinTech adoption and extends the UTAUT to the FinTech area. The proposed model is useful for understanding FinTech adoption behavior as it explores individuals' FinTech adoption from the financial services consumption and technology usage perceptions. In addition, the interactions between the UTAUT constructs and the added constructs were verified in the FinTech context. More specifically, the proposed model has three major theoretical contributions.

First, this study offers a comprehensive perspective to understand FinTech adoption, especially focusing on internet wealth management platforms by integrating perceived value and perceived risk with the core construct of UTAUT. Many e-commerce studies suggest that perceived risk is an inhibitor that hinders the individuals' online adoption intention $[18,69,82]$. In prior technology adoption models, the drivers were studied while 
the obstacles were ignored, generally. The antecedents that affect individuals' adoption behavior are not only facilitating factors but also hindering factors, which are particularly crucial in the FinTech environment. Individuals focus on the FinTech platform's risk because it is not about the system stability but about their wealth. Risk can lead to loss, which could stifle broader adoption. Although there are mixed findings of the perceived risk on individuals' FinTech adoption $[9,16,33]$, the result verified that perceived risk discourages individuals' perceived value and their adoption intention on internet wealth management platforms. Therefore, considering the perceived value and perceived risk could improve the explanation of the proposed model in our context.

Second, this study extends the UTAUT by putting forward that performance expectancy and effort expectancy affect individuals' adoption intention indirectly through perceived value. In this study, the definition of perceived value emphasizes the overall appraisal of the utility of FinTech platforms based on individuals' perception of what they received and the cost. Performance expectancy and effort expectancy are separately related to what is received and the cost. However, prior research ignored the correlation between perceived value and the original variables when they extended the UTAUT with perceived value. One study examined the correlation between perceived value and the original variables of the UTAUT [13]. The authors confirmed the correlation between performance expectancy and perceived value in the mobile commerce context. The correlation between effort expectancy and perceived value was ignored. By clarifying the relationship among perceived value, performance expectancy, and effort expectancy, the UTAUT is further deepened in the FinTech context.

Third, the proposed FinTech adoption model is more effective in the internet wealth management context than the baseline model of the UTAUT, which is widely used to explore the adoption of new technologies. To make the comparison, we extracted measurement items, i.e., performance expectancy, effort expectancy, social influence, and adoption intention, to build the baseline of the UTAUT and executed verification. Facilitating conditions were removed due to them directly affecting individuals' adoption behavior, not their intention in the UTAUT. The results are presented in Figure 3. The core relationship of UTAUT explains $28.3 \%$ of the variance in individuals' FinTech adoption intention, while the proposed FinTech adoption model could explain $65.0 \%$ of the variance. The high variance shows the effectiveness of the FinTech adoption model.

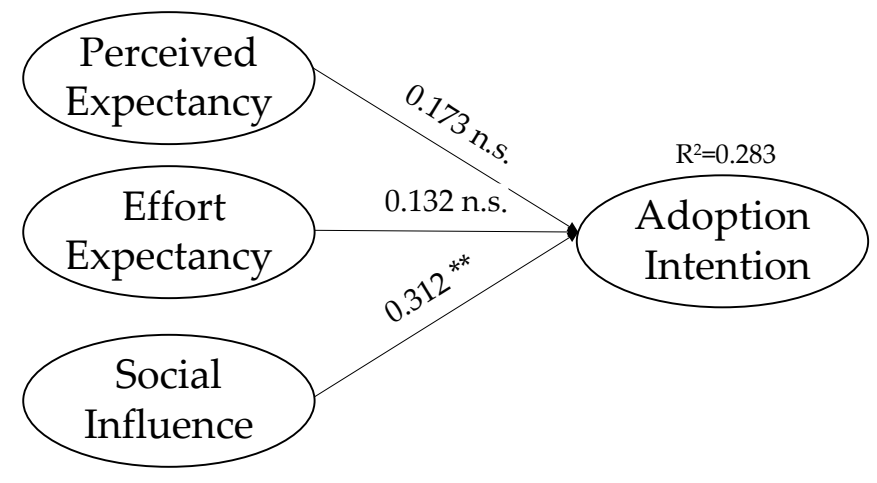

Figure 3. The results of the UTAUT baseline model. Note: ${ }^{* *} p<0.01$; n.s.: no significance.

In conclusion, the proposed model integrating perceived risk and perceived value with the core constructs of the UTAUT is feasible theoretically. Besides, its validity has also been proved since it has high explanatory power.

\subsection{Implications for Practice}

This study has several practical implications for wealth management platforms offered by FinTech companies. Firstly, this study shows that perceived risk profoundly influences individuals' FinTech adoption in wealth management platforms. The risk remains individ- 
uals' concern when using FinTech platforms to manage their wealth. Therefore, FinTech companies should develop a restricted risk management policy. More specifically, FinTech companies should focus on transaction security when launching similar services or products. For example, FinTech companies should emphasize the effort they make to limit the risk of FinTech services on the homepage of the platform. Besides this, FinTech companies could offer insurance when launching financial-related services on FinTech platforms. In addition, FinTech companies could use advanced encryption technologies, such as facial recognition, to enhance the security and stability of the FinTech services they offered.

Another important finding is that performance expectancy and effort expectancy affect individuals' perceived value. The result has implications for the design of user interfaces and sales promotion. FinTech companies can enhance individuals' perceived value of internet wealth management platforms by improving the ease of use and usefulness of their platforms. On the one hand, FinTech companies should simplify the interface and operation process as much as possible during the whole user process (e.g., installation, registration, transaction). For instance, FinTech companies could use fingerprint or facial recognition to $\log$ in to FinTech apps. Meanwhile, FinTech companies could integrate related financial services, such as online payments, money transfer, into the internet wealth management platform. In this way, individuals will improve their performance expectancy and enhance their perceived value when employing internet wealth management platforms.

Based on the results, social influence significantly affects individuals' adoption intention. This finding has implications for the marketing strategy of FinTech companies. For instance, the companies could cooperate with social media to help individuals forward the FinTech services to their friends or families and allow the interface to display the number of friends using the platform. FinTech companies can adopt similar strategies to attract new users to the sales process.

In a word, the findings offer important implications for both incumbents and new entrants to improve their competitiveness and develop their related policy when they launch FinTech services.

\subsection{Limitations}

Although the proposed model has high explanatory power, there are still some limitations. First, this study has shown that the perceived risk is the primary barrier that would hinder the adoption of FinTech platforms. However, this study only theorizes about the impact of perceived risk from a holistic view. Future research could analyze the relationship between perceived risk and adoption intention by assuming the perceived risk is a second-order factor composed of specific facets. Second, the data were collected from China, limiting the generalization of the findings to other countries. Furthermore, cross-cultural comparisons of models between different countries would be significant. Third, this study focuses more on the general exploration of FinTech adoption, not the individual characteristics that are shown as moderators in the UTAUT. Future research could include the four moderators to explore the moderation effect of individual characteristics on the proposed model. Finally, although the total effective sample size meets the minimum sample size suggested by Hair et al. [74], it is still recommended that future studies collect more data to further improve the reliability of the FinTech adoption model.

Despite the limitations, the proposed FinTech adoption model can help researchers and FinTech practitioners to understand individuals' FinTech adoption, especially on internet wealth management platforms.

Author Contributions: Conceptualization, J.X. and W.H.; Data curation, J.X. and M.Y.; Formal analysis, J.X. and M.Y.; Funding acquisition, L.Y. and W.H.; Methodology, J.X., L.Y., and W.H.; Resources, M.Y.; Software, J.X.; Supervision, W.H.; Validation, L.Y.; Writing-original draft, J.X. and M.Y.; Writing-review and editing, L.Y. and W.H. All authors have read and agreed to the published version of the manuscript. 
Funding: This research was funded by National Natural Science Foundation of China (NSFC), grant number 71731009, 72061127002, 2018WZDXM020, 71732006, 71433001, 71722014, 91546119. It was partially funded by Shenzhen Research Base in Arts \& Social Sciences as well as by the National Laboratory of Mechanical Manufacture System at Xi'an Jiaotong University.

Institutional Review Board Statement: Not applicable.

Informed Consent Statement: Informed consent was obtained from all subjects involved in the study.

Data Availability Statement: Not applicable.

Conflicts of Interest: The authors declare no conflict of interest. The funders had no role in the design of the study; in the collection, analyses, or interpretation of data; in the writing of the manuscript; in the decision to publish the results.

\section{Appendix A}

Table A1. Measurement items and sources.

\begin{tabular}{ccc}
\hline Construct & Measurement Items & Source \\
\hline PE1: I find the FinTech wealth management & platform useful in my daily life. \\
PE2: Using the FinTech wealth management & platform increases my chances of capital \\
appreciation. (dropped) & Adapted from [7,50] \\
PE3: Using the FinTech wealth management & flatform improved the utilization rate of my idle \\
PE4: Using FinTech wealth management & platform increases my efficiency of finance \\
management & \\
\hline
\end{tabular}

EE1: It would be easy for me to become skillful at Effort Expectancy EE2: I would find the platform easy to use. EE3: Learning to operate the platform is easy for Adapted from $[7,50]$ me.

PV1: Compared to the effort I need to put in, the use of the FinTech wealth management platform is beneficial to me.

PV2: Compared to the time I need to spend, the

Perceived Value use of the FinTech wealth management platform is worthwhile to me.

PV3: Use of the FinTech wealth management platform reducing financial management costs.

PV4: Overall, the use of the FinTech wealth management platform delivers me good value.

SI1: People who are important to me think that I should use the FinTech wealth management platform.

Social Influence

SI2: People who influence my behavior think that I should use the FinTech wealth management platform.

SI3: People whose opinions that I value prefer that I use the FinTech wealth management platform. (dropped) 
Table A1. Cont.

\begin{tabular}{|c|c|c|}
\hline Construct & Measurement Items & Source \\
\hline Perceived Risk & $\begin{array}{l}\text { PR1: How would you characterize the decision } \\
\text { to transact with the FinTech wealth management } \\
\text { platform? (Significant risk/insignificant risk) } \\
\text { PR2: How would you characterize the decision } \\
\text { to transact with the FinTech wealth management } \\
\text { platform? (Very negative/Very positive situation) } \\
\text { PR3: How would you characterize the decision } \\
\text { to buy a financial product from the FinTech } \\
\text { wealth management platform? (High potential } \\
\text { for loss/High potential for gain) } \\
\text { PR4: How would you rate your overall } \\
\text { perception of risk from the FinTech wealth } \\
\text { management platform? }\end{array}$ & Adapted from $[67,72]$ \\
\hline Facilitating Conditions & $\begin{array}{l}\text { FC1: I have the resources necessary to use the } \\
\text { FinTech wealth management platform, such as } \\
\text { smartphones, relative applications, and so on. } \\
\text { FC2: I know (financial, internet usage) necessary } \\
\text { to use the FinTech wealth management platform. } \\
\text { FC3: I can get help from others when I have } \\
\text { difficulties using the FinTech wealth } \\
\text { management platform. }\end{array}$ & Adapted from $[7,50]$ \\
\hline $\begin{array}{l}\text { Adoption } \\
\text { Intention }\end{array}$ & $\begin{array}{l}\text { AIN1: I intend to continue using the FinTech } \\
\text { wealth management platform in the next few } \\
\text { months. } \\
\text { AIN2: I will always try to use the FinTech wealth } \\
\text { management platform in my daily life. } \\
\text { AIN3: I plan to continue to use the FinTech } \\
\text { wealth management platform frequently. }\end{array}$ & Adapted from $[7,50]$ \\
\hline Adoption Behavior (for robutness test) & $\begin{array}{l}\text { ABE: Please indicate your usage frequency for } \\
\text { FinTech wealth management platforms ("never" } \\
\text { to "many times per day") }\end{array}$ & Adapted from [7] \\
\hline
\end{tabular}

\section{Appendix B}

We used SPSS 26.0 to perform the exploratory factor analysis (EFA). Table A2 shows the item loading. Most reflective indicators in the rotated component matrix were above 0.6 , indicating the construct validity, except the second item of performance expectancy (PE2) and the third item of social influence (SI3). Therefore, PE2 and SI3 were excluded in further analysis. Table A3 has shown the total variance explained, which indicates that the common method biases were not a major threat to the results.

Table A2. Rotated component matrix from SPSS.

\begin{tabular}{cccccccccc}
\hline \multicolumn{2}{c}{ Construct } & $\mathbf{1}$ & $\mathbf{2}$ & $\mathbf{3}$ & $\mathbf{4}$ & $\mathbf{5}$ & $\mathbf{6}$ & $\mathbf{7}$ \\
\hline \multirow{2}{*}{$\begin{array}{c}\text { Performance } \\
\text { Expectancy }\end{array}$} & PE1 & 0.775 & 0.179 & 0.219 & 0.023 & -0.109 & 0.127 & 0.157 \\
(PE) & PE2 & 0.547 & 0.181 & 0.288 & 0.068 & -0.031 & 0.280 & 0.186 \\
& PE4 & 0.659 & 0.263 & 0.155 & 0.117 & -0.046 & 0.279 & 0.110 \\
\hline Effort & EE1 & 0.815 & 0.102 & 0.136 & 0.109 & -0.096 & 0.167 & -0.015 \\
Expectancy & EE2 & 0.193 & 0.709 & 0.050 & 0.137 & -0.059 & 0.223 & -0.001 \\
(EE) & EE3 & 0.095 & 0.768 & 0.162 & 0.028 & -0.026 & 0.184 & 0.114 \\
\hline
\end{tabular}


Table A2. Cont.

\begin{tabular}{ccccccccc}
\hline \multicolumn{2}{c}{ Construct } & $\mathbf{1}$ & $\mathbf{2}$ & $\mathbf{3}$ & $\mathbf{4}$ & $\mathbf{5}$ & $\mathbf{6}$ & $\mathbf{7}$ \\
\hline Social & SI1 & 0.245 & 0.107 & 0.840 & 0.076 & -0.063 & 0.211 & 0.089 \\
Influence & SI2 & 0.230 & 0.091 & 0.804 & 0.169 & -0.025 & 0.223 & 0.188 \\
(SI) & SI3 & 0.273 & 0.306 & 0.574 & 0.147 & -0.081 & 0.272 & 0.142 \\
\hline Facilitating & FC1 & 0.100 & 0.062 & 0.075 & 0.802 & -0.163 & 0.116 & 0.026 \\
Condition & FC2 & 0.055 & 0.129 & 0.062 & 0.845 & 0.022 & -0.017 & 0.082 \\
(FC) & FC3 & 0.067 & -0.022 & 0.111 & 0.827 & 0.076 & -0.009 & 0.003 \\
\hline Perceived & PR1 & -0.067 & -0.062 & -0.048 & 0.025 & 0.808 & -0.092 & -0.229 \\
Risk & PR2 & -0.085 & -0.056 & -0.058 & 0.036 & 0.819 & -0.081 & -0.196 \\
(PR) & PR3 & -0.043 & -0.026 & -0.085 & -0.086 & 0.877 & -0.081 & -0.120 \\
& PR4 & -0.057 & -0.013 & 0.053 & -0.031 & 0.842 & -0.089 & -0.143 \\
\hline Perceived & PV1 & 0.225 & 0.247 & 0.184 & -0.005 & -0.104 & 0.739 & 0.218 \\
Value & PV2 & 0.142 & 0.199 & 0.174 & 0.094 & -0.093 & 0.793 & 0.121 \\
(PV) & PV3 & 0.178 & 0.299 & 0.260 & -0.040 & -0.100 & 0.732 & 0.147 \\
\hline Adoption & PV4 & 0.319 & 0.172 & 0.124 & 0.051 & -0.180 & 0.731 & 0.130 \\
Inten- & AIN1 & 0.194 & 0.201 & 0.139 & 0.046 & -0.308 & 0.148 & 0.767 \\
tion(AIN) & AIN2 & 0.130 & 0.042 & 0.131 & 0.022 & -0.387 & 0.326 \\
\hline
\end{tabular}

Table A3. Total variance explained.

\begin{tabular}{|c|c|c|c|c|c|c|c|}
\hline & \multicolumn{2}{|c|}{ Initial Eigenvalues } & \multicolumn{2}{|c|}{$\begin{array}{c}\text { Extraction Sums of Squared } \\
\text { Loadings }\end{array}$} & \multicolumn{3}{|c|}{ Rotation Sums of Squared Loadings } \\
\hline & Total & $\begin{array}{c}\% \text { of } \\
\text { Variance }\end{array}$ & Total & $\%$ of Variance & Total & $\begin{array}{c}\% \text { of } \\
\text { Variance }\end{array}$ & Cumulative $\%$ \\
\hline 1 & 7.570 & 34.411 & 7.570 & 34.411 & 3.299 & 14.995 & 14.995 \\
\hline 2 & 3.019 & 13.723 & 3.019 & 13.723 & 2.992 & 13.600 & 28.595 \\
\hline 3 & 2.030 & 9.229 & 2.030 & 9.229 & 2.212 & 10.056 & 38.651 \\
\hline 4 & 1.221 & 5.552 & 1.221 & 5.552 & 2.191 & 9.959 & 48.610 \\
\hline 5 & 1.140 & 5.182 & 1.140 & 5.182 & 2.176 & 9.892 & 58.502 \\
\hline 6 & 0.841 & 3.821 & 0.841 & 3.821 & 2.049 & 9.315 & 67.818 \\
\hline 7 & 0.774 & 3.518 & 0.774 & 3.518 & 1.676 & 7.617 & 75.435 \\
\hline 8 & 0.600 & 2.729 & & & & & \\
\hline 9 & 0.549 & 2.497 & & & & & \\
\hline 10 & 0.505 & 2.293 & & & & & \\
\hline 11 & 0.439 & 1.997 & & & & & \\
\hline 12 & 0.425 & 1.930 & & & & & \\
\hline 13 & 0.387 & 1.757 & & & & & \\
\hline 14 & 0.353 & 1.606 & & & & & \\
\hline 15 & 0.340 & 1.545 & & & & & \\
\hline 16 & 0.315 & 1.430 & & & & & \\
\hline 17 & 0.311 & 1.415 & & & & & \\
\hline 18 & 0.282 & 1.280 & & & & & \\
\hline 19 & 0.264 & 1.202 & & & & & \\
\hline 20 & 0.242 & 1.101 & & & & & \\
\hline 21 & 0.219 & 0.995 & & & & & \\
\hline 22 & 0.173 & 0.787 & & & & & \\
\hline
\end{tabular}

\section{Appendix C}

To verify the robustness of our proposed model, we replaced "FinTech platform adoption intention" with self-reported "FinTech platform adoption behavior" and put forward an alternative model. We removed the facilitating conditions because our empirical result has shown that facilitating conditions do not affect the intention. The results of the alternative model show that SI and PV are positively related to individuals' FinTech platform adoption behavior, while PR is negatively related to their adoption behavior. The 
relationships between $\mathrm{PE}, \mathrm{EE}, \mathrm{PR}$, and PV are similar to the proposed model. Although the path coefficient has some changes, the significance of the relationships is consistent. Thus, it confirms the robustness of our proposed model.

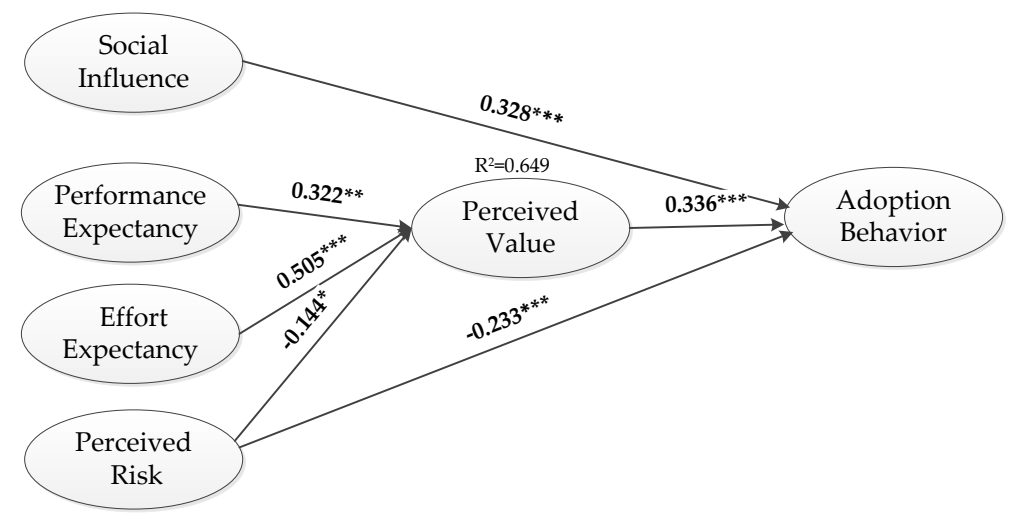

Figure A1. The results of the alternative model. Note: ${ }^{* *} p<0.001 ;{ }^{* *} p<0.01 ;{ }^{*} p<0.05$.

\section{References}

1. Jiang, Y.; Ho, Y.-C.; Yan, X.; Tan, Y. Investor platform choice: Herding, platform attributes, and regulations. J. Manag. Inf. Syst. 2018, 35, 86-116. [CrossRef]

2. Ernst \& Young. Global FinTech Adoption Index 2019. Available online: https:/ / go.ey.com/2CKL3vJ (accessed on 3 June 2019).

3. Gomber, P.; Kauffman, R.J.; Parker, C.; Weber, B.W. On the Fintech revolution: Interpreting the forces of innovation, disruption, and transformation in financial services. J. Manag. Inf. Syst. 2018, 35, 220-265. [CrossRef]

4. Gomber, P.; Kauffman, R.J.; Parker, C.; Weber, B.W. Special issue: Financial information systems and the fintech revolution. J. Manag. Inf. Syst. 2018, 35, 12-18. [CrossRef]

5. Gozman, D.; Liebenau, J.; Mangan, J. The innovation mechanisms of Fintech start-ups: Insights from SWIFT's innotribe competition. J. Manag. Inf. Syst. 2018, 35, 145-179. [CrossRef]

6. Werth, O.; Schwarzbach, C.; Cardona, D.; Breitner, M.; Schulenburg, J.-M. Influencing factors for the digital transformation in the financial services sector. Z. Gesamte Versicher. 2020, 109, 1-25. [CrossRef]

7. Venkatesh, V.; Thong, J.Y.L.; Xu, X. Consumer acceptance and use of information technology: Extending the unified theory of acceptance and use of technology. MIS Q. 2012, 36, 157-178. [CrossRef]

8. Baptista, G.; Oliveira, T. Understanding mobile banking: The unified theory of acceptance and use of technology combined with cultural moderators. Comput. Hum. Behav. 2015, 50, 418-430. [CrossRef]

9. Sharma, R.; Singh, G.; Sharma, S. Modelling internet banking adoption in Fiji: A developing country perspective. Int. J. Inf. Manag. 2020, 53, 102-116. [CrossRef]

10. Maciel, Q.M.; Samuel, F.W. Blockchain adoption challenges in supply chain: An empirical investigation of the main drivers in India and the USA. Int. J. Inf. Manag. 2019, 46, 70-82. [CrossRef]

11. Jansen, J.; van Schaik, P. Testing a model of precautionary online behaviour: The case of online banking. Comput. Hum. Behav. 2018, 87, 371-383. [CrossRef]

12. Jia, L.; Xue, G.; Fu, Y.; Xu, L. Factors affecting consumers' acceptance of e-commerce consumer credit service. Int. J. Inf. Manag. 2018, 40, 103-110. [CrossRef]

13. Shaw, N.; Sergueeva, K. The non-monetary benefits of mobile commerce: Extending UTAUT2 with perceived value. Int. J. Inf. Manag. 2019, 45, 44-55. [CrossRef]

14. Baptista, G.; Oliveira, T. Why so serious? Gamification impact in the acceptance of mobile banking services. Internet Res. 2017, 27, 118-139. [CrossRef]

15. Stewart, H.; Juerjens, J. Data security and consumer trust in FinTech innovation in Germany. Inf. Comput. Secur. 2018, 26, 109-128. [CrossRef]

16. Zhou, W.; Tsiga, Z.; Li, B.; Zheng, S.; Jiang, S. What influence users' e-finance continuance intention? The moderating role of trust. Ind. Manag. Data Syst. 2018, 118, 1647-1670. [CrossRef]

17. Sharma, S.K.; Sharma, M. Examining the role of trust and quality dimensions in the actual usage of mobile banking services: An empirical investigation. Int. J. Inf. Manag. 2019, 44, 65-75. [CrossRef]

18. De Luna, I.R.; Liébana-Cabanillas, F.; Sánchez-Fernández, J.; Muñoz-Leiva, F. Mobile payment is not all the same: The adoption of mobile payment systems depending on the technology applied. Technol. Forecast. Soc. Chang. 2019, 146, 931-944. [CrossRef]

19. Chen, X.; Hu, X.; Ben, S. How individual investors react to negative events in the FinTech era? Evidence from China's Peer-to-Peer lending. J. Theor. Appl. Electron. Commer. Res. 2021, 16, 52-70. [CrossRef] 
20. Jünger, M.; Mietzner, M. Banking goes digital: The adoption of FinTech services by German households. Financ. Res. Lett. 2020, 34, 101260. [CrossRef]

21. Pal Kapoor, A.; Vij, M. How to boost your App store rating? An empirical assessment of ratings for mobile banking Apps. J. Theor. Appl. Electron. Commer. Res. 2020, 15, 99-115. [CrossRef]

22. Okoli, T.; Tewari, D. An empirical assessment of probability rates for financial technology adoption among African economies: A multiple logistic regression approach. Asian Econ. Financ. Rev. 2020, 10, 1342-1355. [CrossRef]

23. Al Nawayseh, M.K. FinTech in COVID-19 and beyond: What factors are affecting customers' choice of FinTech applications? J. Open Innov. Technol. Mark. Complex. 2020, 6, 153. [CrossRef]

24. Kam, B.H.; Riquelme, H. An exploratory study of length and frequency of internet banking usage. J. Theor. Appl. Electron. Commer. Res. 2007, 2, 76-85. [CrossRef]

25. Wei, M.-F.; Luh, Y.-H.; Huang, Y.-H.; Chang, Y.-C. Young generation's mobile payment adoption behavior: Analysis based on an extended UTAUT model. J. Theor. Appl. Electron. Commer. Res. 2021, 16, 37. [CrossRef]

26. Yeh, H. Factors in the ecosystem of mobile payment affecting its use: From the customers' perspective in Taiwan. J. Theor. Appl. Electron. Commer. Res. 2020, 15, 13-29. [CrossRef]

27. Fernando, E. Analysis of the influence of consumer behavior using FinTech services with SEM and TOPSIS. In Proceedings of the 2019 International Conference on Information Management and Technology (ICIMTech), Jakarta/Bali, Indonesia, 19-20 August 2019; pp. 93-97.

28. Kim, H.-W.; Chan, H.C.; Gupta, S. Value-based adoption of mobile internet: An empirical investigation. Decis. Support Syst. 2007, 43, 111-126. [CrossRef]

29. Sirdeshmukh, D.; Singh, J.; Sabol, B. Consumer trust, value, and loyalty in relational exchanges. J. Mark. 2002, 66, 15-37. [CrossRef]

30. Thaler, R. Mental accounting and consumer choice. Mark. Sci. 1985, 4, 199-214. [CrossRef]

31. Zeithaml, V.A. Consumer perceptions of price, quality and value: A means-end model and synthesis of evidence. J. Mark. 1988, 52, 2-22. [CrossRef]

32. Gordon, R.; Dibb, S.; Magee, C.; Cooper, P.; Waitt, G. Empirically testing the concept of value-in-behavior and its relevance for social marketing. J. Bus. Res. 2018, 82, 56-67. [CrossRef]

33. Chopdar, P.K.; Korfiatis, N.; Sivakumar, V.J.; Lytras, M.D. Mobile shopping apps adoption and perceived risks: A cross-country perspective utilizing the Unified Theory of Acceptance and Use of Technology. Comput. Hum. Behav. 2018, 86, 109-128. [CrossRef]

34. Featherman, M.S.; Pavlou, P.A. Predicting e-services adoption: A perceived risk facets perspective. Int. J. Hum. Comput. Stud. 2003, 59, 451-474. [CrossRef]

35. Kahneman, D.; Tversky, A. Prospect theory: An analysis of decision under risk. Econometrica 1979, 47, 263-292. [CrossRef]

36. Thakur, R.; Srivastava, M. Adoption readiness, personal innovativeness, perceived risk and usage intention across customer groups for mobile payment services in India. Internet Res. 2014, 24, 369-392. [CrossRef]

37. Antony, S.; Lin, Z.; Xu, B. Determinants of escrow service adoption in consumer-to-consumer online auction market: An experimental study. Decis. Support Syst. 2006, 42, 1889-1900. [CrossRef]

38. Lee, M.-C. Factors influencing the adoption of internet banking: An integration of TAM and TPB with perceived risk and perceived benefit. Electron. Commer. Res. Appl. 2009, 8, 130-141. [CrossRef]

39. Alalwan, A.A.; Dwivedi, Y.K.; Rana, N.P.; Algharabat, R. Examining factors influencing Jordanian customers' intentions and adoption of internet banking: Extending UTAUT2 with risk. J. Retail. Consum. Serv. 2018, 40, 125-138. [CrossRef]

40. Liu, Y.; Wang, M.; Huang, D.; Huang, Q.; Yang, H.; Li, Z. The impact of mobility, risk, and cost on the users' intention to adopt mobile payments. Inf. Syst. E-Bus. Manag. 2019, 17, 319-342. [CrossRef]

41. Fishbein, M.; Ajzen, I. Belief, Attitude, Intention and Behaviour: An Introduction to Theory and Research; Addison-Wesley: Boston, MA, USA, 1975.

42. Davis, F.D. Perceived usefulness, perceived ease of use, and user acceptance of information technology. MIS Q. 1989, 13, 319-340. [CrossRef]

43. Rogers, E.M. Diffusion of Innovations, 4th ed.; The Free Press: New York, NY, USA, 1995.

44. Davis, F.D.; Bagozzi, R.P.; Warshaw, P.R. User acceptance of computer technology: A comparison of two theoretical models. Manag. Sci. 1989, 35, 982-1003. [CrossRef]

45. Davis, F.D.; Bagozzi, R.P.; Warshaw, P.R. Extrinsic and Intrinsic Motivation to Use Computers in the Workplace1. J. Appl. Soc. Psychol. 1992, 22, 1111-1132. [CrossRef]

46. Ajzen, I. The theory of planned behavior. Organ. Behav. Hum. Decis. Process 1991, 50, 179-211. [CrossRef]

47. Taylor, S.; Todd, P. Assessing IT usage: The role of prior experience. MIS Q. 1995, 19, 561-570. [CrossRef]

48. Thompson, R.L.; Higgins, C.A.; Howell, J.M. Personal computing: Toward a conceptual model of utilization. MIS Q. 1991, 15, 125-143. [CrossRef]

49. Bandura, A. Social Foundations of Thought and Action: A Social Cognitive Theory; Prentice Hall: Hoboken, NJ, USA, 1986.

50. Venkatesh, V.; Morris, M.G.; Davis, G.B.; Davis, F.D. User acceptance of information technology: Toward a unified view. MIS Q. 2003, 27, 425-478. [CrossRef]

51. Oliveira, T.; Thomas, M.; Baptista, G.; Campos, F. Mobile payment: Understanding the determinants of customer adoption and intention to recommend the technology. Comput. Hum. Behav. 2016, 61, 404-414. [CrossRef] 
52. Im, I.; Hong, S.; Kang, M.S. An international comparison of technology adoption. Inf. Manag. 2011, 48, 1-8. [CrossRef]

53. Yang, Q.; Pang, C.; Liu, L.; Yen, D.C.; Michael Tarn, J. Exploring consumer perceived risk and trust for online payments: An empirical study in China's younger generation. Comput. Hum. Behav. 2015, 50, 9-24. [CrossRef]

54. Venkatesh, V.; Thong, J.Y.L.; Xu, X. Unified theory of acceptance and use of technology: A synthesis and the road ahead. J. Assoc. Inf. Syst. 2016, 17, 328-376. [CrossRef]

55. Yang, S.; Lu, Y.; Gupta, S.; Cao, Y.; Zhang, R. Mobile payment services adoption across time: An empirical study of the effects of behavioral beliefs, social influences, and personal traits. Comput. Hum. Behav. 2012, 28, 129-142. [CrossRef]

56. Chiu, Y.-T.H.; Lee, W.-I.; Liu, C.-C.; Liu, L.-Y. Internet lottery commerce: An integrated view of online sport lottery adoption. J. Internet Commer. 2012, 11, 68-80. [CrossRef]

57. Hamari, J.; Koivisto, J. “Working out for likes": An empirical study on social influence in exercise gamification. Comput. Hum. Behav. 2015, 50, 333-347. [CrossRef]

58. Rana, N.P.; Dwivedi, Y.K.; Williams, M.D.; Weerakkody, V. Adoption of online public grievance redressal system in India: Toward developing a unified view. Comput. Hum. Behav. 2016, 59, 265-282. [CrossRef]

59. Oliveira, T.; Faria, M.; Thomas, M.A.; Popovič, A. Extending the understanding of mobile banking adoption: When UTAUT meets TTF and ITM. Int. J. Inf. Manag. 2014, 34, 689-703. [CrossRef]

60. Beach, L.R.; Mitchell, T.R. A contingency model for the selection of decision strategies. Acad. Manag. Rev. 1978, 3, 439-449. [CrossRef]

61. Payne, J.W. Contingent decision behavior. Psychol. Bull. 1982, 92, 382-402. [CrossRef]

62. Sweeney, J.C.; Soutar, G.N. Consumer perceived value: The development of a multiple item scale. J. Retail. 2001, 77, 203-220. [CrossRef]

63. Johnson, E.; Payne, J. Effort and accuracy in choice. Manag. Sci. 1985, 31, 395-414. [CrossRef]

64. Turel, O.; Serenko, A.; Bontis, N. User acceptance of wireless short messaging services: Deconstructing perceived value. Inf. Manag. 2007, 44, 63-73. [CrossRef]

65. Chiu, C.-M.; Wang, E.T.G.; Fang, Y.-H.; Huang, H.-Y. Understanding customers' repeat purchase intentions in B2C e-commerce: The roles of utilitarian value, hedonic value and perceived risk. Inf. Syst. J. 2014, 24, 85-114. [CrossRef]

66. Roy, A. Strategic social marketing. J. Int. Consum. Mark. 2016, 28, 73-74. [CrossRef]

67. Kim, D.J.; Ferrin, D.L.; Rao, H.R. A trust-based consumer decision-making model in electronic commerce: The role of trust, perceived risk, and their antecedents. Decis. Support Syst. 2008, 44, 544-564. [CrossRef]

68. Peter, J.P.; Ryan, M.J. An investigation of perceived risk at the brand level. J. Mark. Res. 1976, 13, 184-188. [CrossRef]

69. Chong, A.Y.L. A two-staged SEM-neural network approach for understanding and predicting the determinants of m-commerce adoption. Expert Syst. Appl. 2013, 40, 1240-1247. [CrossRef]

70. Slade, E.L.; Dwivedi, Y.K.; Piercy, N.C.; Williams, M.D. Modeling consumers' adoption intentions of remote mobile payments in the United Kingdom: Extending UTAUT with innovativeness, risk, and trust. Psychol. Mark. 2015, 32, 860-873. [CrossRef]

71. CNNIC. Statistical Report on Internet Development in China; China Internet Network Information Center: Beijing, China, 2019.

72. Pavlou, P.A. Consumer acceptance of electronic commerce: Integrating trust and risk with the technology acceptance model. Int. J. Electron. Commer. 2003, 7, 101-134. [CrossRef]

73. Brislin, R.W. Back-translation for cross-cultural research. J. Cross-Cult. Psychol. 1970, 1, 185-216. [CrossRef]

74. Hair, J.F.; Black, W.C.; Babin, B.J.; Anderson, R.E. Multivariate Data Analysis, 7th ed.; Pearson Education: London, UK, 2010.

75. Gefen, D.; Rigdon, E.E.; Straub, D. Editor's Comments: An Update and Extension to SEM Guidelines for Administrative and Social Science Research. MIS Q. 2011, 35, iii-xiv. [CrossRef]

76. MacKenzie, S.; Podsakoff, P.; Podsakoff, N. Construct measurement and validation procedures in MIS and behavioral research: Integrating new and existing techniques. MIS Q. 2011, 35, 293-334. [CrossRef]

77. Bentler, P.M.; Bonett, D.G. Significance tests and goodness of fit in the analysis of covariance structures. Psychol. Bull. 1980, 88 , 588-606. [CrossRef]

78. Salisbury, W.D.; Chin, W.W.; Gopal, A.; Newsted, P.R. Research report: Better theory through measurement-Developing a scale to capture consensus on appropriation. Inf. Syst. Res. 2002, 13, 91-103. [CrossRef]

79. Podsakoff, P.M.; MacKenzie, S.B.; Lee, J.Y.; Podsakoff, N.P. Common method biases in behavioral research: A critical review of the literature and recommended remedies. J. Appl. Psychol. 2003, 88, 879-903. [CrossRef] [PubMed]

80. Podsakoff, P.M.; Organ, D. Self-report in organizational research: Problems and prospects. J. Manag. 1986, 12, 531-544. [CrossRef]

81. Yazdanmehr, A.; Wang, J.; Yang, Z. Peers matter: The moderating role of social influence on information security policy compliance. Inf. Syst. J. 2020, 30, 791-944. [CrossRef]

82. Shah, M.H.; Peikari, H.R.; Yasin, N.M. The determinants of individuals' perceived e-security: Evidence from Malaysia. Int. J. Inf. Manag. 2014, 34, 48-57. [CrossRef] 